\title{
THE IMPORTANCE OF SACRUM MORPHOLOGY IN TRANSSACRAL AND ILIOSACRAL SCREW FIXATION
}

\section{Transsakral ve İliosakral Vida Tespitinde Sakrum Morfolojisinin Önemi}

\author{
Serhat DURUSOY ${ }^{1}$, Ahmet Emre PAKSOY ${ }^{2}$ \\ ${ }^{1}$ Yozgat Bozok Üniveritesi Tıp Fakültesi Ortopedi ve Travmatoloji A.D., Merkez, YOZGAT, TÜRKIYE \\ ${ }^{2}$ Atatürk Üniveritesi Tip Fakültesi, Ortopedi ve Travmatoloji A.D., ERZURUM, TÜRKIYE
}

Objective: In this study, it was aimed to put forward the effects of the morphological characteristics of the sacrum on the choice of iliosacral or transsacral screwing.

Material and Methods: The study was carried out on 224 patients who underwent computerized tomographic imaging of the pelvis between May 2016 and May 2019. By reviewing the images of the patients, parameters such as sacrum types, applicability for transsacral screwing, the narrowest diameter of the bone corridor in the coronal plane where the screw was placed properly, and the anteversion angle of the screw were evaluated. Moreover, the distribution of these data according to age and gender was compared between the groups.

Results: Of the patients' sacrums; $72(32.1 \%)$ were the ascending type, $28(12.5 \%)$ were the descending type, 106 $(47.3 \%)$ were the horizontal type, and $18(8 \%)$ were the dysmorphic type. While transsacral screwing could be performed in $136(60 \%)$ of the sacrums, it was not possible in $88(40 \%)$. The width of the narrowest part where the iliosacral screw would pass was 19.52 (52 (min-max:11.8-47)) $\mathrm{mm}$ on average in all patient groups. There was no difference only between the horizontal and the descending types in terms of the narrowest diameter through which the iliosacral screw would pass. The anteversion angle of the iliosacral screw was 25.4 (min-max:5-52.5) degrees on average in all patients. The anteversion angle of the iliosacral screw varied between all sacrum types.

Conclusion: Differences in the sacrum morphology in patients who will undergo iliosacral or transsacral screwing affect the choice of surgery to be applied. For this reason, preoperative surgical planning is essential according to the sacrum morphology.

Keywords: Transsacral screwing, iliosacral screwing, screw anteversion angle, sacral morphology, surgery decision
Amaç: $\mathrm{Bu}$ çalışmada; sakrumun morfolojik özelliklerinin iliosakral veya transsakral vidalama seçimi üzerine olan etkilerinin ortaya konulması amaçlanmıştır.

Gereç ve Yöntemler: Çalışma, Mayıs 2016-Mayıs 2019 yılları arasında pelvis bilgisayarlı tomografi görüntülemesi yapılan 224 hasta üzerinde yapılmıştır. Hastaların görüntülerinden yararlanılarak sakrum tipleri, transsakral vidalama için uygulanabilirlik, uygun yerleşimli vidanın yerleştiği kemik koridorun koronal plandaki en dar çapı ve vidanın anteversiyon açısı gibi parametreler değerlendirilmiştir. Ayrıca elde edilen bu verilerin yaşa ve cinsiyete göre dağılımları da gruplar arasında kıyaslanmıştır.

Bulgular: Hastaların sakrumlarının 72'si $(\% 32,1)$ asendan tip; 28'i $(\% 12,5)$ desendan tip; 106's1 (\%47,3) horizontal tip; 18'i (\%8) dismorfik tipti. Sakrumların 136'sına (\%60) transsakral vidalama yapilabilirken, 88'ine (\%40) transsakral vidalama yapılamıyordu. İliosakral vidanın geçeceği en dar yerin genişliği bütün hasta grubunda ortalama 19,52 (min-max:11.8-47) mm idi. İliosakral vidanın geçeceği en dar çap açısından sadece horizontal ve desenden tip arasında farklılık yoktu. İliosakral vidanın anteversiyon açısı bütün hastalarda ortalama 25,4 (min-max: 5-52.5) dereceydi. İliosakral vidanın anteversiyon açısı bütün pelvis tipleri arasında farklılık göstermekteydi.

Sonuç: İliosakral veya transsakral vidalama yapılacak hastalarda sakrum morfolojisinde görülecek farklılıklar uygulanacak cerrahi seçimi etkiler. Bundan dolayı sakrum morfolojisine göre preoperatif cerrahi planlama elzemdir.

Anahtar Kelimeler: Transsakral vidalama, iliosakral vidalama, vida anteversiyon açısı, sakrum morfolojisi, cerrahi seçim 


\section{INTRODUCTION}

Posterior pelvis fractures occur as a result of highenergy traumas and can cause instability. Surgical treatment is often applied to these fractures with instability. Iliosacral and transsacral screwings are frequently applied percutaneous surgical methods in posterior pelvic fractures $(1,2)$.

In iliosacral screwing, the screw starts from the iliac wing and ends at the S1 vertebral body. In transsacral screwing, the screw enters through the iliac wing on one side and ends at the opposite iliac wing over the S1 vertebral body. Thus, in transsacral screwing, the screw travels a longer distance in the bone and provides a more stable fixation compared to iliosacral screwing. However, both surgical methods require good surgical planning, good imaging, and advanced surgical experience.

Computed tomography (CT) images to be taken before surgery are of great importance in surgical planning $(3,4)$. During planning, the surgical method that can be applied should be evaluated first. Whether there is a safe surgical bone corridor for transsacral screwing, the anteversion angle in iliosacral screwing, the narrowest diameter of the bone corridor where the screw will be placed, determining the screw insertion point and determining the lateral projection of this place should be considered during surgical planning. These parameters are specific to patients due to the differences in the sacrum morphology in each patient. In our study, we aimed to reveal the differences in the sacrum morphology and the effects of these differences on the choice of iliosacral or transsacral screwing.

\section{MATERIALS AND METHODS}

Of 1,545 patients who underwent pelvis CT imaging between May 2016 and June 2019, randomly selected 224 patients (116 [51.8\%] males, 108 [48.2\%] females) were included in the study. Approval of the institutional Clinical Research Ethics Committee was obtained (Date: 16.09.2020, issue number: 2017KAEK-189_2020.09.16_10). Patients who completed skeletal maturation and had pelvis CT images with a slice thickness of $2 \mathrm{~mm}$ or less were included in the study. Patients, who did not complete skeletal maturation, had undergone surgery on the posterior pelvis and had CT image slices greater than $2 \mathrm{~mm}$ were excluded from the study.

By using patients' pelvis CT images, the sacrum type, presence of a notch, anteversion angle of the properly placed iliosacral screw, and the narrowest diameter of the safe surgical bone corridor in the coronal plane were evaluated. In addition, these parameters were compared with each other according to age and gender.

Determination of the Sacrum Type and Presence of Notch

The classification described by Goetze et al. was used to determine the sacrum type (5). According to this classification, the sacrum was classified as ascending, horizontal, descending, and dysmorphic type (Figure 1). The same coronal CT images were used to determine the presence of a notch. The presence of a notch detected in the ala of the sacrum was recorded.

Determination of the Safe Surgical Corridor and the Narrowest Diameter for Iliosacral Screwing in the Coronal Plane

Previous studies were taken as a reference to determine the safe surgical corridor for iliosacral screwing $(6,7)$. In the coronal CT images of the pelvis, a safe surgical bone corridor that would not damage the neurovascular structures and with proper screw placement was determined (Figure 2a). The narrowest point of this determined corridor was measured and recorded (Figure 2b).

\section{Determination of the Screw Anteversion Angle}

Following the determination of the safe surgical bone corridor, the angle between the straight line passing through the midline of this corridor and the line connecting both posterior superior iliac spines were 
calculated as the appropriate screw anteversion angle (c angle) (Figure 3).

\section{Formation of Age Groups}

Patients were divided into three groups according to age. Patients evaluated were aged between 20 and 40 in Group 1 and between 40 and 60 in Group 2. In Group 3 , the patients were over 60 years old.

\section{Statistical Analysis}

The data obtained were uploaded on the packaged statistics software. Firstly, descriptive statistics of the data were produced. Then, it was determined whether the data had a normal distribution. It was found that the data did not have a normal distribution. For this reason, the Kruskal-Wallis test, one of the non-parametric tests, was used to evaluate the difference between the groups. In case of difference between the groups, the Mann-Whitney $U$ test was performed in paired group comparisons. The Bonferroni correction was applied in paired comparisons.

\section{RESULTS}

Of the 224 patients included in the study, 116 were male and 108 were female. Of the patients' sacrums; 72 $(32.1 \%)$ were the ascending type, $28(12.5 \%)$ were the descending type, 106 (47.3\%) were the horizontal type, and $18(8 \%)$ were the dysmorphic type. While transsacral screwing could be performed in $136(60 \%)$ of the sacrums, it was not possible in $88(40 \%)$. While there were no notches in the anterior of the ala of the sacrum in $168(75 \%)$ patients, $56(25 \%)$ had notches (Table 1).

The width of the narrowest part where the iliosacral screw would pass was 19.52 (min-max: 11.8-47) mm on average in all patient groups. The width of the narrowest part where the iliosacral screw would pass was found as $18.4(13.4-24.7) \mathrm{mm}$ on average in the ascending type, $20.25(15.5-24.1) \mathrm{mm}$ on the average descending type, $20.80(11.8-47) \mathrm{mm}$ on average in the horizontal type, and 15.27 (12.1-19.9) $\mathrm{mm}$ on average in the dysmorphic type according to the sacrum types. In the comparison of the narrowest part where the iliosacral screw would pass according to the sacrum types, there was no statistical difference only between the descending type of sacrum and the horizontal type sacrum $(p>0.05)$. There was a significant difference between the other sacrum types (Table 2$)(\mathrm{p}<0.05)$.

The anteversion angle of the properly placed iliosacral screw was 25.4 (5-52.5) degrees on average in all patients. The anteversion angle of the properly placed iliosacral screw according to the sacrum types was 30 (10.6-44.2) degrees on average in the ascending type of sacrum, 17.97 (5-27.2) degrees on average in the descending type sacrum, 22.33 (6.5-34.7) degrees on average in the horizontal type sacrum, and 36.72 (24.954.5) degrees on average in the dysmorphic type sacrum. In the comparison of the anteversion angle of the properly placed iliosacral screw according to the sacrum types, there was a statistical difference between all the sacrum types (Table 2$)(\mathrm{p}<0.05)$.

The width of the narrowest part where the iliosacral screw will pass differs significantly according to the male and female gender $(\mathrm{p}<0.05)$. While this distance is $18.43(11.8-47) \mathrm{mm}$ on average in women, it is 20.53 (12.4-46.5) $\mathrm{mm}$ on average in men. There is no difference between the anteversion angles of the properly placed iliosacral screw according to gender $(\mathrm{p}>0.05)$.

No statistically significant difference was detected between the width of the narrowest part where the iliosacral screw would pass and the anteversion angle of the properly placed iliosacral screw according to age groups $(\mathrm{p}>0.05)$. 
Table 1: Demographic and clinical characteristics of the cases

\begin{tabular}{|c|c|c|c|}
\hline & & & $\mathbf{p}$ \\
\hline \multirow[t]{2}{*}{ Gender $(n=224)$} & Male & $116(51.8 \%)$ & \\
\hline & Female & $108(48.2 \%)$ & \\
\hline \multirow[t]{2}{*}{ Presence of notch } & Present & $56(25 \%)$ & \\
\hline & Not present & $168(75 \%)$ & \\
\hline \multirow[t]{4}{*}{ Sacrum types } & Ascending type & $72(32.1 \%)$ & \\
\hline & Horizontal type & $106(47.3 \%)$ & \\
\hline & Descending type & $28(12.5 \%)$ & \\
\hline & Dysmorphic type & $18(8 \%)$ & \\
\hline \multirow[t]{4}{*}{ Transsacral screwing applicability } & Ascending type & $8 / 72(11.1 \%)$ & \\
\hline & Horizontal type & $106 / 106(100 \%)$ & \\
\hline & Descending type & $28 / 28(100 \%)$ & \\
\hline & Dysmorphic type & $0 / 18(0 \%)$ & \\
\hline \multirow[t]{4}{*}{ The narrowest part of the safe surgical bone corridor (mm) } & Ascending type & 18.4 (min-max:13.4-24.7) & \multirow{4}{*}{$0.000^{*}$} \\
\hline & Horizontal type & 20.80 (min-max:11.8-47) & \\
\hline & Descending type & $20.25(\min -\max : 15.5-24.1)$ & \\
\hline & Dysmorphic type & $15.27(\min -\max : 12.1-19.9)$ & \\
\hline \multirow[t]{4}{*}{ Anteversion angle of the iliosacral screw (degree) } & Ascending type & 30 (min-max:10.6-44.2) & \multirow{4}{*}{$0.000 *$} \\
\hline & Horizontal type & 22.33 (min-max:6.5-34.7) & \\
\hline & Descending type & 17.97 (min-max:5-27.2) & \\
\hline & Dysmorphic type & $36.72(\min -\max : 24.9-54.5)$ & \\
\hline
\end{tabular}

*: Kruskal-Wallis test; $\mathrm{p}<0.05$

Table 2: Comparison of sacrum types in respect of the narrowest diameter and screw anteversion angle

\begin{tabular}{llcc}
\hline Group 1 & Group 2 & The narrowest diameter (p-value*) & Anteversion angle (p-value*) \\
Ascending & Descending & 0.004 & 0.000 \\
& Horizontal & 0.000 & 0.000 \\
& Dysmorphic & 0.000 & 0.000 \\
\hline Descending & Horizontal & 0.939 & 0.005 \\
& Dysmorphic & 0.000 & 0.000 \\
\hline Horizontal & Dysmorphic & 0.000 & 0.000 \\
\hline
\end{tabular}

*: Mann-Whitney U test; $\mathrm{p}<0.05$; Bonferroni correction was applied. 


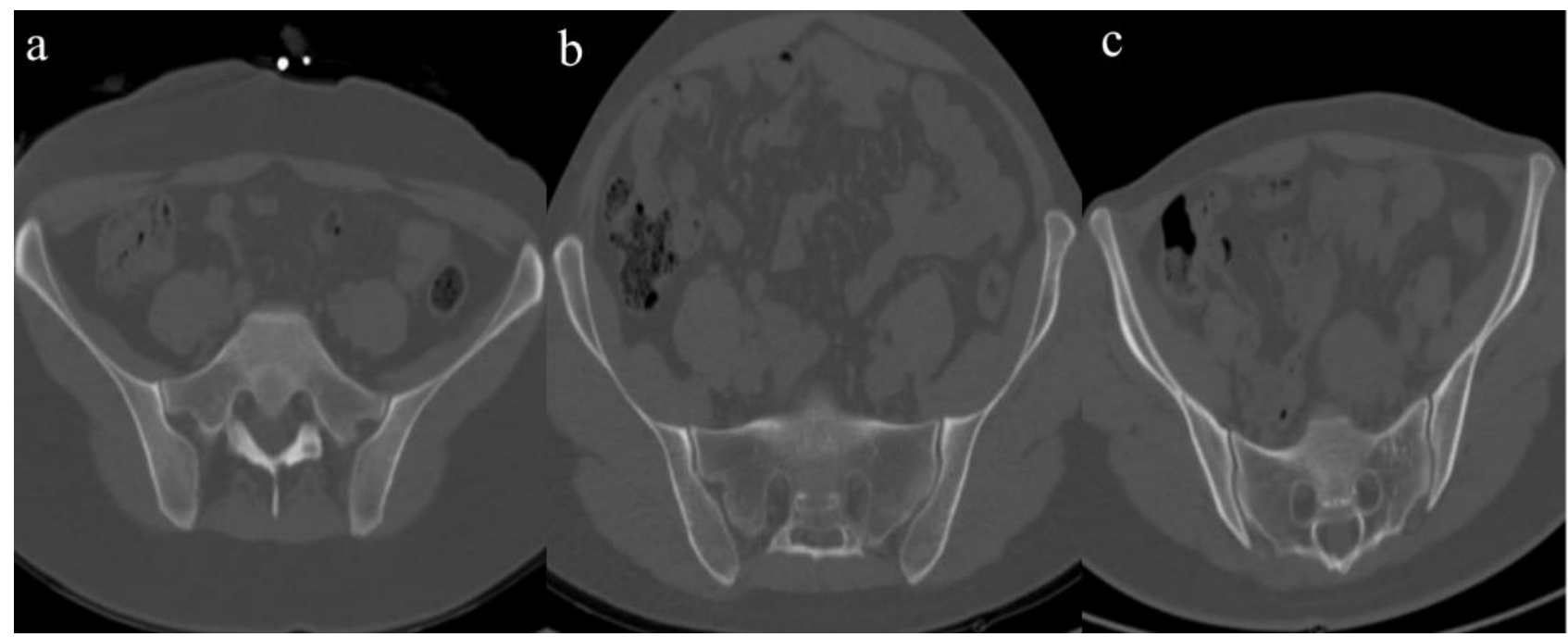

Figure 1: a) Ascending type sacrum, b) Horizontal type sacrum, c) Descending type sacrum

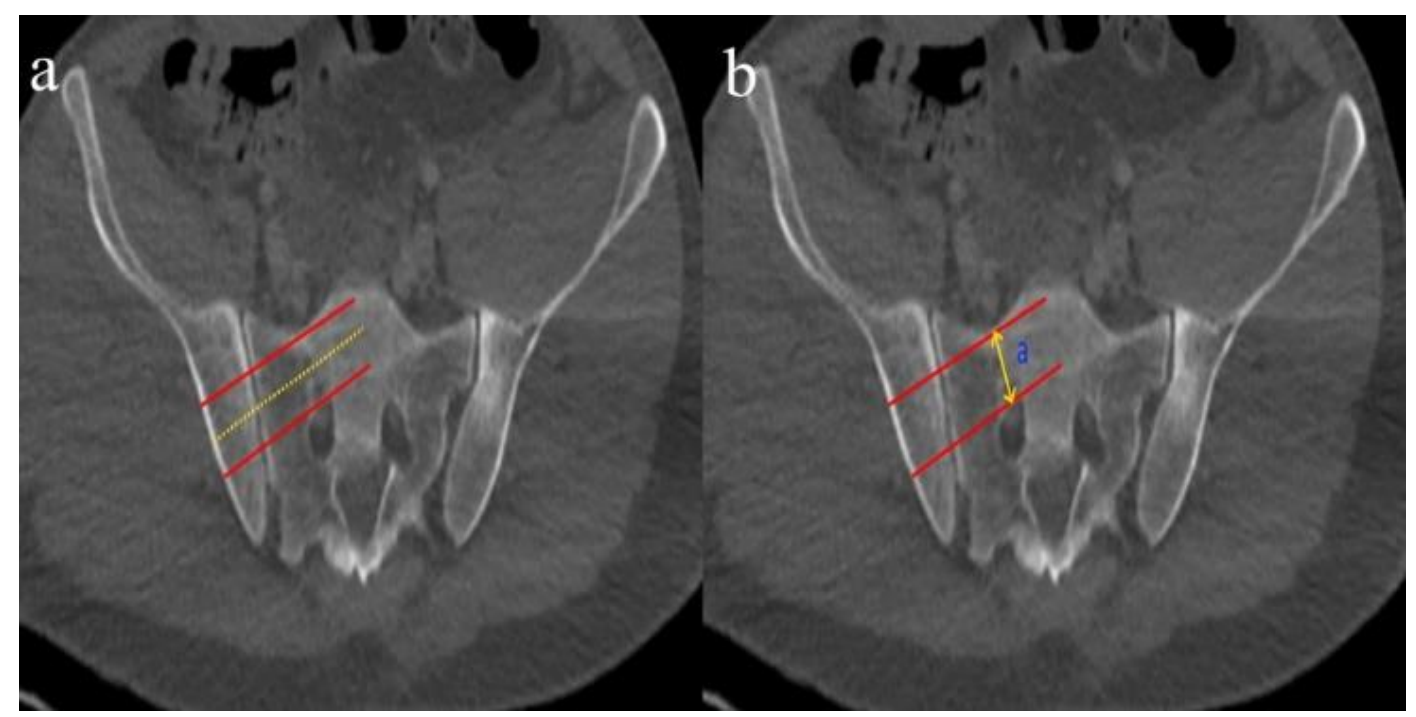

Figure 2: a) Determination of the safe surgical corridor, b) Measurement of the narrowest part of the safe surgical corridor

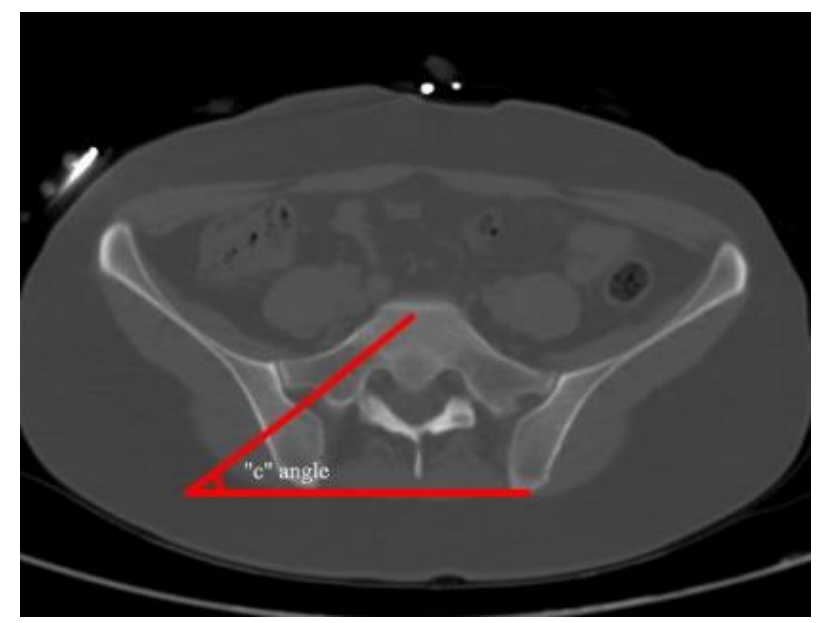

Figure 3: Measurement of the anteversion angle of the properly placed screw 


\section{DISCUSSION}

Iliosacral and transsacral screwings are the percutaneous surgical methods frequently used in posterior pelvis injuries. In iliosacral screwing, the screw enters through the ilium and ends in the sacral vertebral body whereas, in transsacral screwing, the screw enters through the ilium, bypasses the sacral vertebral body, and ends in the opposite ilium. There is more bone involvement in transsacral screwing compared to iliosacral screwing. This increases surgical stability.

Both techniques have become the primary choices of surgeons owing to their minimally invasive nature, short duration of surgery, low blood loss, soft tissue damage, and infection risk. However, some requirements are needed in order to reduce the complication rates that may be encountered during the application of these techniques. These requirements consist of advanced surgical experience, good surgical planning and imaging. Surgical treatment becomes open to complications, particularly in cases where good surgical planning cannot be made. Bastian et al. give importance to this issue in their studies (8). Similarly, many studies in the literature have emphasized the importance of preoperative planning $(9,10)$. We think that changes in the sacral morphology will influence the preoperative surgical planning and reduce the margin of error during surgery.

In posterior pelvic region surgeries, individual-specific changes in the pelvic anatomy change the preference for iliosacral or transsacral screwing. In transsacral screwing, the range of motion in which you can direct the screw is narrower than in iliosacral screwing. Thus, the possibility of encountering complications is higher in transsacral screwing. In their studies, Maslow et al. demonstrated that the superior gluteal neurovascular bundle was at higher risk in terms of injury, particularly in transsacral screwing at the S1 vertebral level (11). They suggested that iliosacral screwing on the S1 vertebra and transsacral screwing on the S2 vertebra would reduce this risk.

Most of the studies on pelvis morphology have focused on the dysmorphic sacrum. Miller et al. described the osseous properties of the dysmorphic sacra in their study (12). Mendel et al., on the other hand, reported that, for iliosacral screwing in the dysmorphic sacra, there was no transverse corridor in the S1 vertebra where the screw could pass, and transverse screwing should be performed from the S2 vertebra (3). Similarly, Conflitti et al. recommend screwing from the S2 vertebra (13). Moreover, they showed in their studies that the S2 vertebra had a wider osseous corridor than the S1 vertebra, and sacral dysmorphism was observed in the population by approximately $35 \%$. Gardner et al. revealed that sacral dysmorphism was observed in the population by $44 \%$, and there were no suitable corridors for transsacral screwing in the S1 vertebras of these sacra (14). In our study, we encountered sacral dysmorphism at a rate of $18 \%$ and we could not find a suitable corridor for transsacral screwing at the S1 vertebra level in our patients with dysmorphic sacrum.

In studies, the sacrum described as normal are compared with the sacrum described as dysmorphic. It should be remembered that there are morphological changes in the sacrum described as normal. We can see this best in the study conducted by Goetzen et al. (1). Goetzen et al. classified the normal sacrum as ascending, horizontal and descending types. The effects of sacrum types used in this classification on surgical planning are discussed in the studies of Durusoy et al (15). In this study, it is reported that the screw insertion location may change depending on the sacrum types, especially in the lateral projection. For this reason, they recommend mapping of the sacrum before surgery. In a similar study, Krappinger et al. described the preoperative planning in the sacrum, which are defined as normal (7). In this study, the angles of the iliosacral screws with the ground plane 
vary according to the sacrum type. The angle mentioned here is similar to the screw anteversion angle in our study. As in the study of Goetzen et al., we also revealed in our study that sacrum types could differ in the population. Additionally, we discovered that all horizontal and descending type sacrums and only $11.1 \%$ of the ascending types had a surgical bone corridor suitable for transsacral screwing. It should be kept in mind that there may be no suitable bone corridors for transsacral screwing in the ascending type sacrum, which is described as a normal situation. Supporting Krappinger et al., we found that the screw anteversion angles were different in each sacrum type according to the sacrum types. These angles determined preoperatively will enable the predetermination of the angle of insertion of the iliosacral screw during surgery.

In a study assessing the change of pelvic anatomy according to gender, it was demonstrated that the safe surgical bone corridor, where the screw would pass, for the S1 vertebral body was wider in men (4). In another study, Gras F. et al. revealed that the corridor through which the screw would pass was narrower in women, and sacral dysmorphism was more common (16). Accordingly, they suggested that the bone corridor was more suitable for iliosacral screwing in men. Similarly, Weigelt $\mathrm{L}$ et al. set forth that female patients with dysmorphic sacrum had smaller sacroiliac joints, and sacral dysmorphism was more common in the population (17). Contrary to these studies, Balling et al. showed that women had more suitable routes for transsacral screwing in the lower region of the S1 vertebra (18). They also argued that changes in the sacral morphology were independent of gender. In line with the data we have obtained, we do not agree with Balling et al. In our study, the safe surgical bone corridor in women was narrower than in men. There was no difference between men and women in terms of the screw anteversion angle according to gender.
In our study, we could not detect any difference in the sacrum morphology according to age groups. Accordingly, the morphological structure of the sacrum is homogeneously distributed among age groups.

Our study has some limitations. The low number of patients is one of the limitations of the study. The fact that the study was carried out in a single center is another limitation of the study. This situation prevented us from evaluating the effects of the ethnic characteristics, which, we thought, had effects on the sacrum morphology, in a country like Turkey, where ethnic diversity is high. We believe that this limitation will be eliminated, and the Turkish population will be represented better if a study is conducted with more than one center.

Consequently, the morphological properties of the sacrum differ from person to person. This situation influences the preference for iliosacral and transsacral screwing. We think that revealing the morphological properties of patients' sacrum during preoperative planning will reduce probable complications. It should be kept in mind that a suitable bone corridor for transsacral screwing may not be found, particularly in the ascending and dysmorphic sacrum types. Surgical combinations should be shaped accordingly. In parallel with the data obtained in the study, we see that the presence of notches is at high rates. We recommend that this situation should be identified in preoperative planning, and then, steps should be taken accordingly.

\section{Footnote:}

This study was uploaded as an oral presentation in the 1st Virtual Totbid Congress.

Conflict of Interest: $\mathrm{T}$ The authors declare that they have no conflict of interest.

Support and Acknowledgements: There is no funding source.

Researchers' Contribution Rate Statement: The contribution rate of Serhat Durusoy in the article is 
$70 \%$. Serhat Durusoy contributed to the study on the following issues: planning the study, statistical analysis, data collection and analysis, interprention of data, drafting the article or revising it critically and final approval of the version. The contribution rate of Ahmet Emre Paksoy in the article is $30 \%$. Ahmet Emre Paksoy contributed to the study on the following issues: planning the study, interprention of data and final approval of the version.

Ethical Committee Aproval: Yozgat University Clinical Research Ethics Committee, date: 16.09.2020, issue number: 2017-KAEK-189_2020.09.16_10.

\section{REFERENCES}

1. Gardner MJ, Routt MLC. Transiliac-transsacral screws for posterior pelvic stabilization. J Orthop Trauma. 2011;25(6):378-84.

2. Gras F, Hillmann S, Rausch S, Klos K, Hofmann GO, Marintschev I. Biomorphometric analysis of ilio-sacro-iliacal corridors for an intra-osseous implant to fix posterior pelvic ring fractures. J Orthop Res. 2015;33(2):254-60.

3. Mendel T, Noser H, Kuervers J, Goehre F, Hofmann GO, Radetzki F. The influence of sacral morphology on the existence of secure S1 and S2 transverse bone corridors for iliosacroiliac screw fixation. Injury. 2013;44(12):1773-9.

4. Trikha V, Gaba S, Kumar A, Mittal S, Kumar A. Safe corridor for iliosacral and trans-sacral screw placement in Indian population:A preliminary CT based anatomical study. J Clin Orthop Trauma. 2019;10(2):427-31.

5. Goetzen M, Ortner K, Lindtner RA, Schmid R, Blauth M, Krappinger D. A simple approach for the preoperative assessment of sacral morphology for percutaneous SI screw fixation. Arch Orthop Trauma Surg. 2016;136(9):1251-7.
6. Carlson DWA, Scheid DK, Maar DC, Baele JR, Kaehr DM. Safe placement of S1 and S2 iliosacral screws: The "Vestibule" concept. J Orthop Trauma. 2000;14(4):264-9.

7. Krappinger D, Lindtner RA, Benedikt S. Preoperative planning and safe intraoperative placement of iliosacral screws under fluoroscopic control. Oper Orthop Traumatol. 2019;31(6):46573.

8. Bastian JD, Jost J, Cullmann JL, Aghayev E, Keel MJB, Benneker LM. Percutaneous screw fixation of the iliosacral joint: Optimal screw pathways are frequently not completely intraosseous. Injury. 2015;46(10):2003-9.

9. Rommens PM, Nolte EM, Hopf J, Wagner D, Hofmann A, Hessmann M. Safety and efficacy of 2D-fluoroscopy-based iliosacral screw osteosynthesis: results of a retrospective monocentric study. Eur J Trauma Emerg Surg. 2020. Doi:10.1007/s00068-020-01362-9.

10. Yinger K, Scalise J, Olson SA, Bay BK, Finkemeier CG. Biomechanical comparison of posterior pelvic ring fixation. J Orthop Trauma. 2003;17(7):481-7.

11. Maslow J, Collinge CA. Risks to the superior gluteal neurovascular bundle during iliosacral and transsacral screw fixation: A computed tomogram arteriography study. J Orthop Trauma. 2017;31(12):640-3.

12. Miller AN, Routt MLC. Variations in sacral morphology and implications for iliosacral screw fixation. J Am Acad Orthop Surg. 2012;20(1):8-16.

13. Conflitti JM, Graves ML, Chip Routt ML. Radiographic quantification and analysis of dysmorphic upper sacral osseous anatomy and associated iliosacral screw insertions. J Orthop Trauma. 2010;24(10):630-6.

14. Gardner MJ, Morshed S, Nork SE, Ricci WM, Chip Routt ML. Quantification of the upper and second 
sacral segment safe zones in normal and

dysmorphic sacra. J Orthop Trauma.

2010;24(10):622-9.

15. Durusoy S, Paksoy AE, Korkmaz M, Solak AŞ,

Dağlar B. Is pelvic mapping applicable in iliosacral screw fixation to determine screw entry point and screw trajectory? Eklem Hast ve Cerrahisi. 2019;30(3):252-8.

16. Gras F, Gottschling H, Schröder M, Marintschev I, Hofmann GO, Burgkart R. Transsacral osseous corridor anatomy is more amenable to screw insertion in males: a biomorphometric analysis of 280 pelves. Clin Orthop Relat Res. 2016;474(10):2304-11.

17. Weigelt L, Laux CJ, Slankamenac K, Ngyuen TDL, Osterhoff G, Werner CML. Sacral Dysmorphism and its Implication on the Size of the Sacroiliac Joint Surface. Clin Spine Surg. 2019;32(3):140-4.

18. Balling H. Gender-associated differences in sacral morphology do not affect feasibility rates of transsacral screw insertion. radioanatomic investigation based on pelvic cross-sectional imaging of 200 individuals. Spine (Phila Pa 1976). 2020;45(7):421-30. 